\title{
Making the absent present: political parties and emigrant issues in country of origin parliaments \\ Forthcoming in Party Politics
}

\author{
Eva Østergaard-Nielsen \\ Department of Political Science \\ Autonomous University of Barcelona
}

And

Irina Ciornei

Institute for Sociology

University of Bern

Funding: This research was funded by the Spanish Ministry of Economy and Competition, CSO2010-16535.

\section{Acknowledgements:}

We thank Katjuscha Mattu, Guillem Ripoll and Emanuela Le Ménahèze and for their invaluable research assistance and our colleagues Eva Marie-Euchner and Andrea Caggese as well as two anonymous referees for their very helpful comments on previous drafts. 


\begin{abstract}
:
A growing number of countries have granted their emigrant citizens the right to vote in homeland elections from afar. Yet, there is little understanding of the extent to which emigration issues are visible in the subsequent legislative processes of policy making and representation. Based on an original dataset of parliamentary activities in Spain, Italy, France and Romania, this paper analyses why political parties pay attention to emigrants. To that end we propose a conceptual framework which draws on both theories of issue salience and substantive representation. Bridging these two frameworks allows us bring in both parties (salience) and constituencies (representation) in the analysis of the linkage between electorates and parliaments at a transnational level. We test a series of hypothesis and find that parties are more likely to focus on emigration issues the stronger their electoral incentives and in the context of electoral systems allowing the emigrants to elect special emigrant representatives.
\end{abstract}

Keywords: parties, salience, representation, migration, transnational 


\section{Introduction}

Parties and parliaments are facing the challenge of how to deal with an increasingly mobile electorate. The last decades have witnessed an exponential growth of the number of countries that extend citizenship rights to national citizens who reside abroad (Rhodes \& Harutyunyan 2010). These rights include welfare assistance, support for cultural activities and absentee voting rights. Indeed, in 2007 no less than 115 countries allowed emigrants to vote in elections in their countries of origin (Ellis et al. 2007). This incorporation of emigrants in the politics of their country of origin challenges classical notions of territorial democratic representation.

Studies of these phenomena mainly focus on identifying the normative and empirical underpinnings of why countries grant external citizenship to their non-resident citizens (Bauböck 2007; Waldinger \& Soehl 2013; Lafleur 2012). In contrast, there is little understanding of the extent to which external voting rights, paraphrasing Pitkin (1967), render the absent emigrants present in the subsequent processes of policy making and representation (but see, Collyer 2014; Lafleur 2012). Given the dominant trend of enfranchising emigrants it is therefore timely to further probe into the transnational dynamics of the representative linkage between non-resident citizens and their homeland parliaments. What is the general level of attention to emigrant issues in homeland parliaments? And why are some political parties more concerned than others?

Issue salience and substantive representation are two of the main theoretical approaches employed in the study of parliamentary activities. Although issue salience has mainly been applied to the study of electoral campaigns, a growing body of research argues that this theoretical approach is also suitable for the study of party behaviour in parliaments 
(Green-Pedersen 2010; Vliegenthart \& Walgrave 2011). According to salience theories, parties emphasize those issues that that they 'own' or that give them an advantage in the eyes of the electorate (Budge \& Farlie 1983; Laver 2001; Pogorelis et al. 2005; GreenPedersen 2010). However, studies of issue salience rarely include the significance of the relationship between parties and particular local or socially based constituencies such as those of immigrants or emigrants.

The second approach is related to theories of substantive representation and policy responsiveness and centre on individual MPs and their focus on their local constituency or special constituents such as immigrants. Representation theories explain how and why MPs focus on social groups such as women, minorities, immigrants and, broadly speaking, 'local constituents'. This approach offers meaningful insights into the representative link between emigrant constituencies and their special representatives (Heitshusen et al. 2005; Martin 2011; Saalfeld 2011). However, this representative link does not only relate to individual MPs, but is also one of the main democratic linkages between parties and citizens (Dalton et al. 2011). Given that representation theories do not fully engage with how and why parties link up with constituency issues beyond the individual level of the MPs, they cannot explain why homeland political parties focus on emigration in parliamentary contexts without special emigrant representatives.

Building on both sets of theories, the initial assumption of this paper is that emigrants possessing external citizenship rights constitute both an issue and a group of voters for homeland political parties. While all parties in the homeland parliament may have a position regarding emigration, not all of them dedicate the same amount of attention to emigrant related issues and demands. We propose that a framework combining issue 
salience and substantive representation approaches can explain transnational dynamics of salience and representation of emigrants. In turn, this contributes to the understanding of how to bridge studies of salience of constituency issues with studies of the representation linkages between parties and constituencies.

In the empirical part of the paper, we analyse variation in how much political parties emphasize emigration related issues based on an original dataset of parliamentary questions and legislative proposals in four countries: France, Italy, Spain and Romania. These four countries all have sizeable groups of citizens abroad, but their systems of external voting rights differ. Spain, like most countries with external voting rights, counts the emigrant vote as part of the general pool of votes in the constituency of their last residence in the country of origin. France, Romania and Italy belong to the small but growing number of countries (only 13) in which the citizens living abroad elect their own emigrant representatives to the parliament of their country of origin (Collyer 2014). In these electoral systems the emigrants constitute a separate external constituency which is divided into electoral districts for which a determined number of parliamentary seats are reserved.

We test a series of hypothesis related to the electoral support of emigrants in homeland elections, the ideology of parties, the particular electoral system in place and the dynamics of competition for the emigrant vote. Our main findings show that transnational dynamics of representation and issue salience are not so different from the dynamics at the national level despite the volatility and unpredictability of the emigrant vote. Parties are more likely to pay attention to emigrant issues in political systems with 
special emigrant representation and when they receive stronger electoral support from the emigrants.

\section{Emigration salience and the representative link in homeland parliaments}

This section discusses the extent to which we can bring back in parties when explaining why parliaments pay attention to issues such as local and regional constituencies or social groups such as emigrants, immigrant voters or national minorities.

\section{Homeland parliaments and emigration salience}

Issue salience is defined as the relative emphasis given to an issue by political parties in public discourses, electoral campaigns or parliaments (Budge \& Farlie 1983; Laver 2001; Rohrschneider \& Whitefield 2008; Green-Pedersen 2010). Unlike spatial models of party competition, salience theory predicts that parties compete by emphasizing (making salient) issues that are favourable to them or which are perceived as 'owned' by them (Budge 2001; Laver 2001). The relationship between issue salience and issue position is an ongoing discussion. On the one hand, Budge (2001) suggests that the general left-right placement of parties is subject to the particular emphasis on issues in party manifestos. Other studies argue for a further separation of the position and salience of parties (Laver 2001; Pogorelis et al. 2005; Bélanger \& Meguid 2008). In this view, salience denotes the sum of all positions regarding an issue (neutral, pro or against), while position refers to the substantive view of the party on a specific issue. In this paper we adopt the notion of salience as largely separate from position given that we are identifying the amount of attention parties give to emigration rather than their fundamental position on emigration related policies. 
Research on issue salience has identified several explanations for why parties tend to emphasise some issues rather than others. A basic tenet is that the vote-seeking strategies of parties lead them to accentuate issues that make them look good in the eyes of the voters in comparison to the opponent (Petrocik 1996; Budge \& Farlie 1983; Laver 2001). This type of behaviour leads to issue ownership in the long run. An underlying element of the vote-seeking motivation is related to the catering to a particular voter support base (Petrocik 1996; Pogorelis et al. 2005).

In the case of emigrant voters, the identification of core supporters is a challenge for homeland political parties. As noted in other studies of external voting rights it is more costly to mobilize an external electorate dispersed in several countries (Ellis et al. 2007; Lafleur 2012). Moreover, the political preferences of the external electorate are largely un-polled in between elections. However, if a party identifies the emigrant collectives as a part of its electoral support base, then it has a stronger incentive to maintain and establish a link with the external voters who then again are more likely to vote for that party. Hence, parties which receive a larger share of emigrant votes are likely to pay more attention to emigration issues than parties which receive a marginal support $(\mathrm{H} 1)$.

Ideology is another important determinant of issue salience. There are certain issues that are closer to a specific party ideology and which are owned by parties both during electoral campaigns and their parliamentary activities. However, not all ideologically important issues are related to a particular social group of voters, nor are all issues linked to a particular ideology (Pogorelis et al. 2005). For instance, recent research disputes the role of leftist parties being the main party emphasizing immigrant related issues (Alonso \& Fonseca 2012). The link between emigration and ideology is still to be 
further explored. Joppke (2003) argues that while leftist parties have historically pushed for reforms in favour of immigrant inclusion, the rights of non-resident emigrant citizens have been the promoted by the political right. Yet, an inclusive position towards emigrants among right-wing parties does not exclude that leftist parties pay attention to emigration issues. Since the salience of the issue of emigration is not necessarily the same as a positioning on emigration, it is relevant to explore if right-wing parties are indeed dedicating the largest amount of attention to emigration issues. We therefore test if right-wing parties are more likely than left-wing parties to emphasize emigration issues in their parliamentary activities (H2).

\section{Homeland parliaments and emigrant representation}

Emigrants are both an issue and a group of voters with different arrangements of representation across political systems. However, one limitation of the issue salience literature in parliamentary contexts is that it prioritizes the electoral link between parties and voters over the link between parties and constituencies. The focus on constituency interests occupies an important proportion of MPs' legislative and non-legislative activities but it remains unexplored at the level of parties (Martin 2011; Green-Pedersen \& Mortensen 2010; Heitshusen et al. 2005). It is therefore relevant to further explore why parties put different emphases on issues that correspond to a specific group of voters, interest groups or local constituencies.

The answer to this question comes to a large extent from the substantive representation literature, even though most of this research focuses on individual MP behaviour (Powell 2004; Celis 2008; Bird et al. 2010; Saalfeld \& Bischof 2012). These studies argue that factors such as the electoral system and constituency-related electoral 
incentives tend to determine the representative behaviour of MPs and the extent to which they emphasise constituency-related issues in legislative and non-legislative activities.

In terms of constituency-related electoral incentives, the marginality hypothesis suggests that MPs elected by a narrow margin tend to pay closer attention to the interests of their constituency (Griffin 2006; Fiorina 1973; Cox \& Munger 1989; Matsusaka 1993). Drawing on this literature, we expect that the relationship between closer electoral races and the subsequent representation of interests will also be reproduced in the case of party focus on emigrant issues. For instance, there are examples of the emigrant vote being decisive in Romanian presidential elections, Italian legislative elections and Spanish regional elections over the past decade (ØstergaardNielsen \& Ciornei 2013). It is plausible therefore that the competing parties are more likely to emphasize emigration issues in the next legislative period when the emigrant vote is won with a close margin (H3).

Another set of explanations centre on the electoral system. Comparative studies of electoral systems have found that differences in type of ballot impact the representation strategies of parties (Farrell \& Scully 2005). These studies distinguish between majoritarian and proportional electoral systems and degrees of openness of the ballot design and compare the subsequent level of constituency engagement of MPs. The openness of the ballot is a variable that takes into account both the degree to which the voters may have a say in who is elected and if the ballot is candidate-based or party based. The overall suggestion is that majoritarian plurality systems or systems with an open party lists favour a 'personal vote' rendering MPs more prone to create a 
representative linkage with the voters (Heitshusen et al. 2005; Patzelt 2007; Mcleay \& Vowles 2007).

The special representation arrangements for emigrants take different forms and therefore cannot be placed in a clear-cut category. Nevertheless, a plurality electoral system is more comparable to electoral systems where emigrants elect special emigrant representatives than to the cases where the external electorate votes in a homeland constituency, especially if the homeland electoral system is based on closed lists. In electoral systems with special emigrant representatives, the emigrants belong to a clearly delimitated constituency and their representatives are likely to have more incentives to nurture the connection with the constituents than otherwise. The extent to which special emigrant representatives are concerned with emigrant constituent issues is likely to inform the agenda of their parties in parliament. In turn, this attention can spill over to heightened awareness among the rest of the parties. Consequently, it is expected that in contexts with special emigrant representation, emigration issues are more present in party parliamentary activities than in those contexts without special emigrant representation (H4).

The electoral system is expected not only to have a direct impact on the variation of emigration salience among parties, but also to moderate the significance of electoral incentives such as electoral support and closeness of the race. Thus, if the emigrant vote is counted among the domestic vote, it does not necessarily constitute an incentive for increased party focus on emigrant issues. Parties may not have enough resources to dedicate to the (marginal) proportion of emigrant voters when domestic constituencies are large and complex. In those cases, incentives such as gaining an emigrant social 
base or winning in close races among emigrants may only lead to small benefits. It is therefore likely that the effect of high levels of support among the emigrant electorate is stronger in contexts with special emigrant representation (H5). Following a similar reasoning, it is likely that that the effect of high levels of electoral competition among the emigrant electorate is stronger in contexts with special emigrant representation (H6).

\section{The case selection}

The subsequent analysis tests the abovementioned hypotheses by looking at the legislative and non-legislative activities of political parties in the national parliaments of Spain, France and Romania and Italy. These cases are mainly chosen because they differ in terms of the type of external electoral system, which is one of the core explanatory variables of this study. We compare the parties in Italy with directly elected emigrant representatives in both chambers with Spain where the emigrant citizens cast their votes in the last constituency of residence. To this contrast we add France which until 2012 only had indirectly elected special emigrant representatives in the Senate and Romania which changed to special representation in 2008 (see Table 1). Because of the French case we choose to compare chambers of parliament rather than whole

parliaments. ${ }^{1}$ The time frame analysed for Spain is 2000-2011, for France it is 19972012 and for Romania it is 2000-2012. This time period covers three legislatures, except in the case of Italy where we can only include the last two legislatures (2006-2013) when emigrants had long-distance voting rights.

The four countries all have sizeable numbers of emigrants residing abroad, but the geographical spread vary (see table 1). The information on the characteristics of the 
different emigrant groups is sparse and they are unlikely to be homogeneous. For instance, the overall profile of the Spanish and Italian emigrants is likely to be more mixed as second, and third generation Spanish citizens join the pool of external voters. The Romanian voters are, especially in the period under scrutiny, fairly unknown to the political parties.

Moreover, Spain and France have a long trajectory of voting rights for emigrants (France at the presidential level and through electoral colleges for the Senate), while the first elections with long-distance voting in Italy and Romania were celebrated in 2006 and 2001 respectively (Ellis et al. 2007). The systems of registration and voting modalities differ across the countries which has an important impact on the turnout. Notably, the Romanian emigrants are estimated to have an extremely low turnout which likely relates to the fact that until 2016 Romanian external voters could only vote in person at the consulates and embassies whereas the other three emigrant nationalities have the possibility of postal voting and voting by proxy (Østergaard-Nielsen \& Ciornei 2013). The political profile of these emigrants is also different. Past electoral results reveal a stable pattern of centre-right voting in the case of French emigrant voters, and centre-left voting in the case of Italian emigrant voters. In the cases of Romania and Spain the voting pattern is volatile (Lugilde 2007; Østergaard-Nielsen \& Ciornei 2013). Indeed, the Spanish emigrants have always voted for the incumbent government, going against the domestic support for the opposition in 1996, 2004, and 2011 (with a very small margin in the latter election). ${ }^{2}$ Consequently, Spanish parties cannot take their emigrant electoral support for granted.

\section{TABLE 1 HERE}




\section{Data and methods}

\section{Measuring party emphasis on emigration related issues}

The unit of analysis is the number of questions and legislative proposals respectively per party per chamber during a legislature. We include all parties with parliamentary representation during our period of study. We have chosen parliamentary questions and legislative proposals as the two main indicators to estimate the degree of salience of emigration issues among parties. ${ }^{3}$ Other researchers have argued that the volume of parliamentary questions is a relevant indicator of issue salience and constituency focus among political parties and MPs because they indicate which issues grasp the attention of the political representatives (Martin 2011; Saalfeld 2011; Saalfeld \& Bischof 2012; Green-Pedersen 2010; Russo 2011). It is important to emphasize that we focus on visibility of emigrant related issues and therefore include also questions and legislation on, for example, raising taxes and administrative consular fees for expatriates, that are not necessarily welcomed by the emigrants themselves. In addition we analyse the determinants of emigration salience in legislative proposals. Legislative proposals are more time-consuming to prepare and attract more attention from external actors such as media, voters or competitor parties. Consequently parliamentary proposals constitute a stronger commitment and indicator of party attention to emigration. In order to differentiate between government emigration policy and parliamentary focus on emigration, we chose only legislative proposals from the floor. While the former can be an indicator of the concern with emigration of ruling parties, they are not fully comparable to proposals made by elected representatives who have fewer resources for preparation of proposals at their disposal. 
We searched for emigration related parliamentary questions and legislative proposals made by each party. In order to identify the questions and legislative proposals related to emigrants we used key search words that refer to emigrants and emigration in the online search engines of the respective chambers (table 2). The choice of these keywords was based on a previous survey of the legal texts and political discourses on the topic over the last two decades.

Table 2. Examples of keywords used in the search on emigration questions and initiatives

\begin{tabular}{|c|c|c|c|c|}
\hline France & Italy & Romania & Spain & English \\
\hline $\begin{array}{l}\text { français à } \\
\text { l'étranger, } \\
\text { français } \\
\text { établis } \\
\text { hors de } \\
\text { France }\end{array}$ & $\begin{array}{l}\text { italiani } \\
\text { all'estero }\end{array}$ & $\begin{array}{l}\text { romani din } \\
\text { afara } \\
\text { granitelor, } \\
\text { romani de } \\
\text { pretutindeni, } \\
\text { romani din } \\
\text { strainatate, } \\
\text { strainatate }\end{array}$ & $\begin{array}{l}\text { españoles en el } \\
\text { exterior, } \\
\text { residentes } \\
\text { ausentes }\end{array}$ & $\begin{array}{l}\text { French abroad, French living outside of } \\
\text { France, Italians abroad, Romanians abroad, } \\
\text { Romanians outside borders, abroad, } \\
\text { Spaniards abroad, absent residents, } \\
\text { For all countries: emigrants, diaspora, } \\
\text { citizens abroad, residents abroad, } \\
\text { French/Italians/Romanians/Spaniards + 'residing } \\
\text { in' or 'in the world' or 'in + top five } \\
\text { destination countries'. } \\
\text { Main councils/departments for emigrants in } \\
\text { each country. }\end{array}$ \\
\hline
\end{tabular}

We revised all entries and discarded those unrelated to emigration issues. ${ }^{4}$ Based on a pre-established list of codes, we coded their content and summed up the total numbers of both relevant questions/interpellations and legislative proposals per party per chamber in each legislature. ${ }^{5}$ In terms of content, we coded all emigration related questions and legislative proposals from the latest legislature in each country. Based on previous studies on external citizenship, we established a list of categories related to the literature on socio-economic, identity and electoral dimensions of external citizenship (Bauböck 2007; Tintori 2012) as well as a screening of questions. Subsequently, we divided the questions into six broad categories: external voting, culture and education (cultural activities and programmes, emigrant associative sector, education and training 
supported by the state of origin), transnational welfare and protection (pensions, subsidies, financial help to poor emigrants, administrative concerns), fiscal issues (such as taxes, remittances, loans), nationality, social impact in the home country and return (impact for emigrant families, brain drain, return measures). A seventh category called 'other' refers to other topics that were not deemed frequent enough to merit a category of their own.

\section{Determinants of party emphasis on emigration related issues}

Emigrant electoral support is a continuous variable representing the percentage of emigrant votes a party received in the election before each legislature, measured on a 0 100 scale. Although the variable on voter support is temporally prior to the legislative activities under scrutiny, the causality between emigrant electoral support and party emphasis on emigrant issues cannot be determined in this analysis. However, the correlation between these two variables is interesting in and of itself in a transnational electoral field with an often volatile emigrant vote. Since there is no special representation of Spaniards abroad, the variable is calculated as the share of votes received from abroad by a party over the total number of votes from abroad. In the case of France, emigrants did not vote in legislative elections until 2012 and we therefore use the results of the presidential elections to measure emigrant voter preferences for political parties in the National Assembly. In the case of the French Senate we use the results of the indirect elections of emigrant senators through the 155 member electoral college for emigrants (Assemble de Francais a l'Etranger/Assembly of French Abroad). ${ }^{6}$ 
We measure ideology on a continuous scale from 1 (left) to 10 (right) according to the data available in the Chapel Hill Expert Survey (CHES) database. ${ }^{7}$ The closeness of the electoral competition is operationalized as a continuous variable that measures the difference in percentages between the first and second most voted parties among emigrant voters. The smaller the difference of votes, the larger is the closeness of the electoral competition. The variable related to the system of special representation for emigrants is a dummy that takes the value 1 when the system recognizes a special emigrant constituency and 0 otherwise.

\section{Control variables}

It may be the case that only large national parties, which have the resources to establish an enduring connection with the emigrant communities, are at the same time their advocates in the national parliaments. We therefore control for the size of the party in each of the parliamentary chambers. The variable is calculated as the percentage of seats of the respective party or group in the chamber (0-100 scale). Moreover, we control if the party is in government with the party in government taking the value of 1 and opposition parties taking the value of 0 . We expect that parties in government are less likely to submit private members' bills. We also control if the impact of ideology is stronger in systems of special representation. This type of representation may strengthen the visibility and endurance of the ideological link between parties and external voters since parties' activities are easier communicated to and evaluated by the external constituents. Since the variation in parties' attention to emigration issue is influenced by contextual factors such as parliamentary traditions and the overall volume of questions and legislative proposals in one national parliament or chamber, we introduce country dummies and chamber dummies. ${ }^{8}$ In order to address the temporal dimension of the 
study, we control for the particular legislature in which the question or legislative proposal was introduced.

\section{Methods}

In order to analyse the data we estimate negative binomial models. Negative binomial models are recommended in order to handle over dispersed data where the variance is higher than the mean (Hilbe 2011) and have previously been used in the analysis of parliamentary activities on other issues such as immigration (Saalfeld \& Bischof 2012). In our dataset, the average number of questions per party is 19.45 with a standard deviation of 52.71. A similar data pattern is reproduced in each of the countries studied. In the case of legislative proposals, the average for all countries is 2.30 with a standard deviation of 5.28. The percentage of emigration questions and initiatives over the total number of questions and initiatives respectively made by a party also displays a high level of dispersion. Given that negative binomial models can only handle count data we discard using the percentage of emigration questions as our dependent variable.

\section{Findings}

\section{Emigration salience in homeland parliaments}

External voting has received widespread interest in the literature on citizenship. Yet, with the exception of the Spanish Senate, this issue occupies a relatively small part of emigration related parliamentary questions (Figure 1). The salience of external voting in Spain is related to especially the opposition's concern with fraud in the emigrant voter registration, resulting in the 2011 law on tighter registration requirements and the 
abolishment of external voting rights in local elections. Romania, France and Italy also experienced debates and parliamentary questions regarding the electoral integrity of the vote from abroad. Arguments related to the district boundaries of the French constituencies and the risk of fraud in the proposed postal voting systems in Romania or the ongoing postal voting system in Italy are examples of some of the issues that dominated parliamentary questions and declarations within this area.

An important part of the parliamentary questions concerns the transnational welfare and protection of emigrants. This includes issues of social and financial assistance for emigrants in need and improvement of consular services. Topics related to culture and education occupy, between a fifth and a fourth of emigration related questions in each country. Issues of return and social impact of emigration are questioned by especially Spanish and Romanian parliamentarians. In the case of Spain, this is related to changes in the nationality laws in the mid-2000, which facilitated return migration of second and third generation Spanish nationals from especially Latin American countries. In the context of more recent emigration in Romania, concerns with the 'children left behind' by the emigrated parents or the brain drain in several economic sectors are examples of questions in this category. Italian and French parliamentarians have paid most attention to the issue of the emigrant 'tax payer'. This includes concern with tax evasion and expatriates' financial duties (property or income taxes) or entitlements (bank accounts, transactions). Curiously Romania, the worlds' $10^{\text {th }}$ largest recipient of remittances (World Bank 2008), has witnessed little debate on this topic. The questions on the emigrant taxpayer and the integrity of the external vote illustrate that attention to emigrants can be critical and evolve around restricting rights and expanding obligations to the homeland. 
Legislative proposals follow a somewhat different dynamic than parliamentary questions (Figure 2). The external vote dominates the attention of especially French and Italian parliamentarians. These proposals focus on the improvement of registration and voting procedure in order to avoid fraud and gerrymandering, and also on the reform of non-electoral representation bodies such as the Assembly of French Abroad (AFE) or the Committees for the Italians Abroad. Proposals related to transnational welfare receive attention in all countries except for Romania. This finding is most likely explained by the recent character of the Romanian migration and patterns of circular and temporary migration. Culture and education as well as fiscal issues are salient areas for especially Italian and Romanian deputies.

Figure 1. Emigration related parliamentary questions by country and chamber during the latest legislature

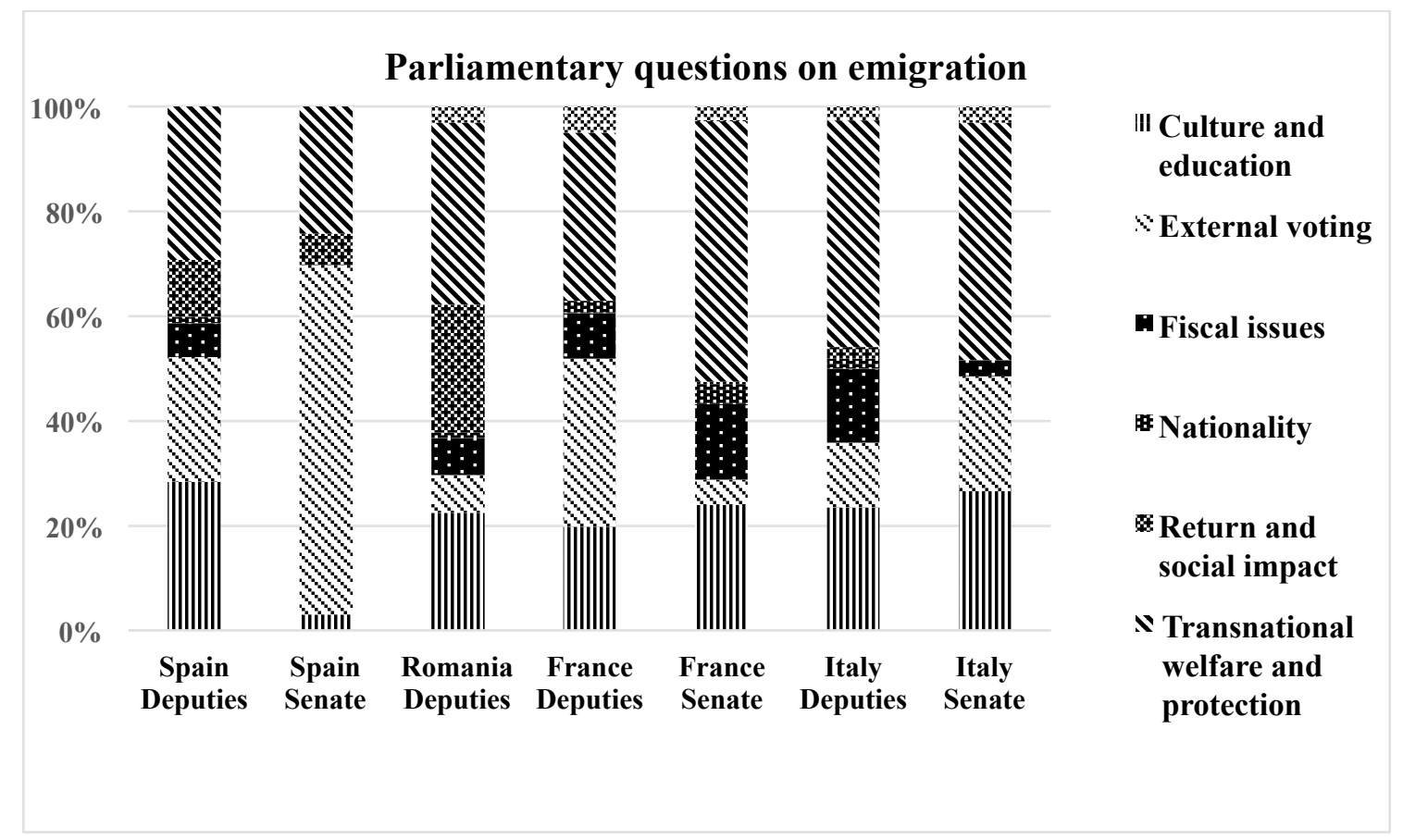


Figure 2: Emigration related legislative proposals by country and chamber during the latest legislature.

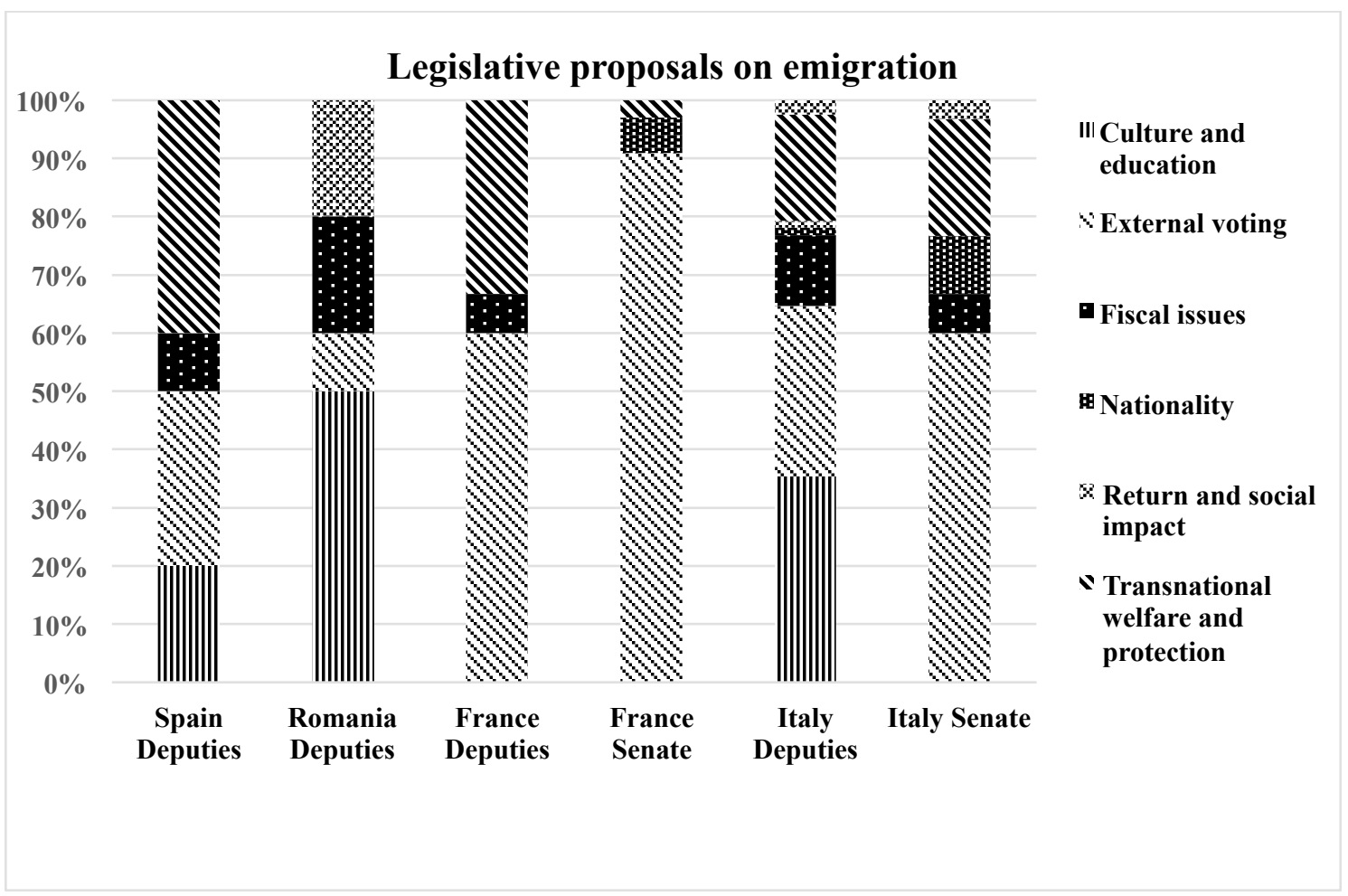

Emigration salience and special representation

Complete data has been collected on 173 cases (a party per legislative chamber per legislative period) across the four countries. Across the three legislatures, 57 mainly very small parties have no activity related to emigration. The largest parties tend to be more attentive to emigrant issues, with the French Union for a Popular Movement (UMP) asking the largest number of questions (430) and the Italian Democratic Party (PD) and the People of Freedom Party (PdL) making the largest number of proposals (34 each). During the period studied, the increase in the salience of emigration in parliamentary questions is uneven across the cases. The number of questions increases in the case of Italy and Romania. In the case of the latter this coincides with the 
introduction of special emigrant representatives in the latest legislature (see table 3 ). In terms of legislative proposals the number increases in all cases except Spain.

The extent to which special emigrant representatives are responsible for the attention to emigrants varies across cases. The representation of the French abroad is almost entirely carried out by the emigrant senators, which have a long-standing tenure in the French Senate. However, in contexts with more recent representation arrangements such as Italy and Romania the proportion of questions and initiatives made by emigrant representatives varies between 11 and 81 percent and with significant variation across the chambers and parties. The extent to which and why emigrant representative 'take over' the issue of emigration is worthy of further investigation. For now we note that in Romania and Italy there is a much less stable pattern of emigrant issue delegation than in the case of France. Emigration continues to be a salient issue for the party rather than an area that is exclusively carried out by the elected MPs.

Table 3. Number of emigration related questions per chamber and special representatives

\begin{tabular}{|l|l|l|l|l|}
\hline Country & Chamber & Legislature I & Legislature II & Legislature III \\
\hline Spain & Total Congress & 160 & 116 & 92 \\
\hline & Total Senate & 241 & 50 & 33 \\
\hline Romania & Total Chamber of Deputies & 12 & 76 & 98 \\
\hline & $\%$ by special emigrant representatives & & & 23.47 \\
\hline France & Total National Assembly & 82 & 192 & 81 \\
\hline & Total Senate & 626 & 654 & 438 \\
\hline & $\%$ by special emigrant representatives & 77.32 & 91.28 & 88.58 \\
\hline Italy & Total Chamber of Deputies & & 110 & 268 \\
\hline & $\%$ by special emigrant representatives & & 54.55 & 67.91 \\
\hline & Total Senate & & 30 & 64 \\
\hline & $\%$ by special emigrant representatives & & 43.33 & 34.38 \\
\hline
\end{tabular}

Table 4. Number of emigration related legislative proposals per chamber and special representatives

\begin{tabular}{|l|l|l|l|l|}
\hline Country & Chamber & Legislature I & Legislature II & Legislature III \\
\hline Spain & Total Congress & 24 & 9 & 10 \\
\hline Romania & Total Chamber of Deputies & 2 & 8 & 15 \\
\hline & \% by special emigrant representatives & & & 40.00 \\
\hline France & Total National Assembly & & 5 & 15 \\
\hline & Total Senate & 8 & 20 & 33 \\
\hline
\end{tabular}




\begin{tabular}{|l|l|l|l|l|} 
& \% by special emigrant representatives & 62.5 & 100 & 100 \\
\hline Italy & Total Chamber of Deputies & & 36 & 82 \\
\hline & $\%$ by special emigrant representatives & & 80.55 & 74.39 \\
\hline & Total Senate & & 9 & 30 \\
\hline & $\%$ by special emigrant representatives & & 11.11 & 40 \\
\hline
\end{tabular}

\section{Determinants of emigration salience in parliamentary questions}

In order to test the hypotheses proposed we present four sets of negative binomial regressions which test the relevance of emigrant electoral support, party competition and an electoral system of emigrant representation for the number of emigration questions proposed by each party (per chamber) in one legislature (table 5). Model 1 tests the impact of explanatory variables without interaction terms and shows that the electoral system and electoral support among emigrant voters are significant predictors for the variation of emigrant issue salience on party agendas. Electoral support by emigrants is a factor that is positively correlated with the salience of emigration in parties' non-legislative activities, confirming H1. One percentage increase in emigrant votes increases the log-odds of making emigration related questions by 0.044 . In incidence ratios (not shown here), the rate for emigration related questions would be expected to increase by a factor of 1.04 while holding all other variables in the model constant and increasing the emigrant vote for one party by one per cent.

In terms of the connection between party ideology and emigration, the coefficient of the variable ideology is not statistically significant. This suggests that parties placed on the right are not necessarily more attentive to emigrant issues in parliamentary questions, contradicting $\mathrm{H} 2$. This finding can be interpreted in various ways. As suggested by previous studies (Joppke 2003; Tintori 2012) centre right parties may be drivers of emigrant enfranchisement and more inclusive reforms of electoral regulations regarding the vote from abroad. However, our dataset includes a broader set of issues such as 
transnational welfare, culture or education, which may be closer to the general agenda of centre left parties. Further studies, which break down the content of the questions across the different legislatures, are needed in order to confirm this interpretation. In terms of the electoral system, the results confirm that an electoral system with special representation has a positive effect on party attention to emigration issues (H4). The introduction of special representation arrangements for external citizens has a strong impact on emigration salience on homeland party agenda, as it increases the incidence ratio of emigration related parliamentary questions by a factor of 7.27.

Models 2-4 test if an electoral system with special emigrant representatives modifies the impact and significance of electoral incentives (such as emigrant support and closeness of electoral competition) and ideology. The interaction between the electoral system and emigrant electoral support is not significant rendering H5 not confirmed. This means that parties that are better placed among emigrants' preferences also become their advocates in homeland parliaments regardless of the type of electoral system.

Table 5. Determinants of volume of emigration related parliamentary questions. Negative binomial coefficients with robust standard errors.

\begin{tabular}{|c|c|c|c|c|}
\hline & (1) & (2) & (3) & (4) \\
\hline Emigrant electoral & $0.044^{* * *}$ & $0.046^{* * *}$ & $0.041^{* * *}$ & $0.044^{* * *}$ \\
\hline & $(0.009)$ & $(0.011)$ & $(0.010)$ & $(0.009)$ \\
\hline Ideology & $\begin{array}{l}-0.007 \\
(0.068)\end{array}$ & $\begin{array}{l}-0.007 \\
(0.068)\end{array}$ & $\begin{array}{l}-0.016 \\
(0.069)\end{array}$ & $\begin{array}{l}-0.010 \\
(0.114)\end{array}$ \\
\hline $\begin{array}{l}\text { Closeness of electoral } \\
\text { competition }\end{array}$ & -0.006 & -0.006 & $0.030^{*}$ & -0.006 \\
\hline Special representation & $\begin{array}{l}(0.015) \\
1.984^{* * *} \\
(0.387)\end{array}$ & $\begin{array}{l}(0.015) \\
2.104^{* *} \\
(0.574)\end{array}$ & $\begin{array}{l}(0.017) \\
3.815^{* * *} \\
(0.783)\end{array}$ & $\begin{array}{l}(0.015) \\
1.956^{*} \\
(0.802)\end{array}$ \\
\hline $\begin{array}{l}\text { Special representation\# } \\
\text { Emigrant electoral } \\
\text { support }\end{array}$ & & -0.006 & & \\
\hline $\begin{array}{l}\text { Special representation\# } \\
\text { Closeness of electoral } \\
\text { competition }\end{array}$ & & $(0.015)$ & $-0.083^{* *}$ & \\
\hline
\end{tabular}




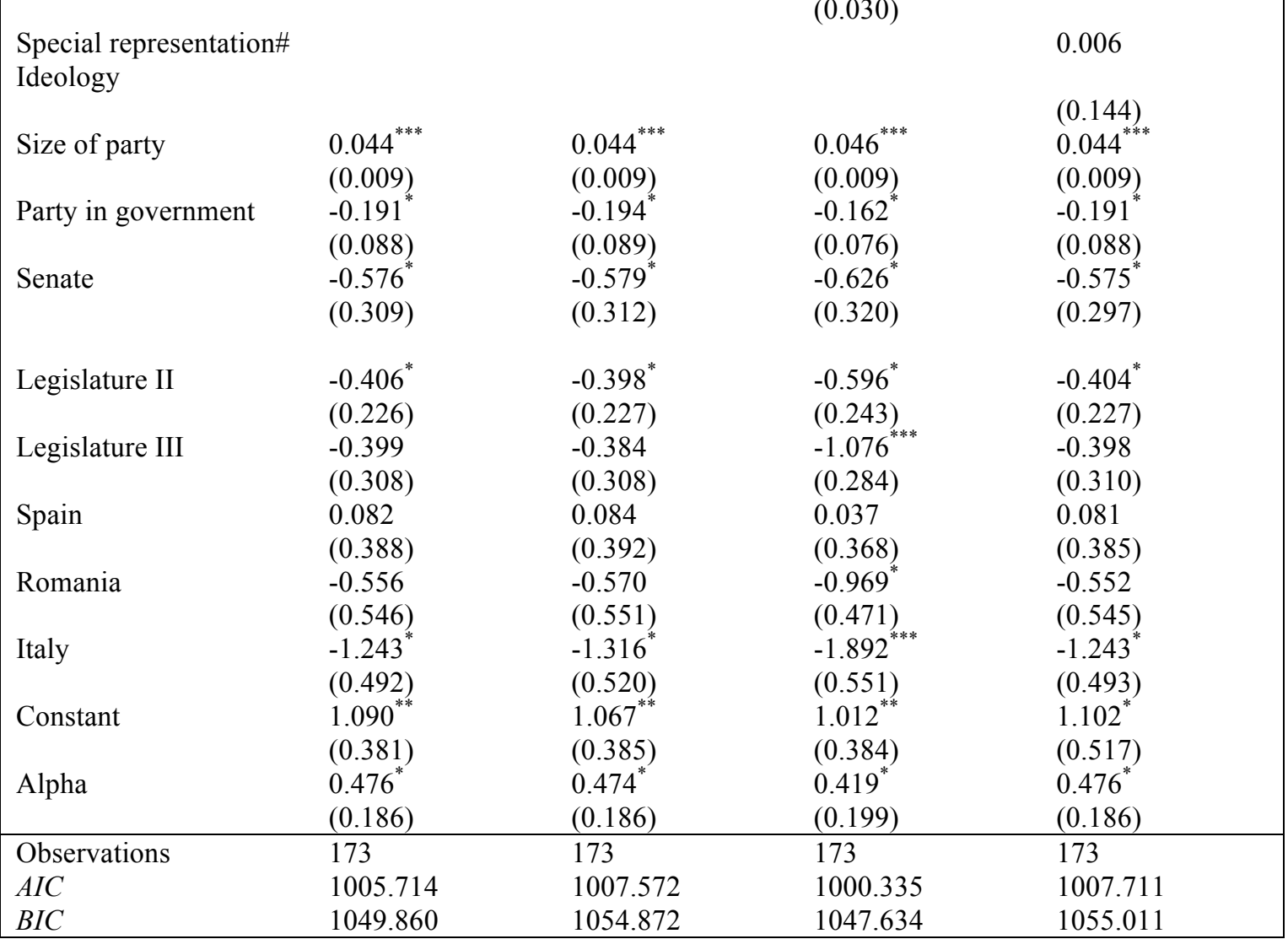

Standard errors in parenthesis

Base categories: Legislature: Legislature I; Country: France ${ }^{*} p<0.1,{ }^{* *} p<0.01,{ }^{* * *} p<0.001$

As Model 3 indicates, the interaction between the closeness of the electoral competition and special representation is significant. This means that closer electoral races have a stronger effect on party attention to emigrant issues in electoral systems with special representatives than in those where the external vote is counted in a domestic constituency. This finding confirms H6. For a better interpretation of this result, we calculate the predicted number of questions in contexts with/without special representation and different degrees of electoral competition. In systems with special representation the number of emigration related questions decreases from 103 to 36 when the distance between the two most voted parties increases from five percent to 25 percent. In contexts without special representation the closeness of the results has an opposite effect, albeit much smaller. The number of questions changes from 11 to 20 
when the distance between the most voted parties increases from five percent to 25 percent.

Regarding the control variables, all models show that the size of the party in one chamber has a strong significant effect on emigration salience. This finding shows that it is the larger, and by extension more resourceful parties, which are more likely to focus on emigration issues. Moreover, given the combination of a government dominated legislative process and party discipline, participation in government decreases the share of emigration related questions made by one party in the four sets of multivariate regressions. As Model 4 shows, the impact of ideology remains insignificant and uniform across cases, irrespective of the type of electoral system in place. As predicted, parties in the upper chambers are less likely to ask emigration related questions in comparison to their counterparts in the lower chambers. This finding is explained by the fact that across our countries of study, the upper chambers have fewer seats and consequently the output of the non-legislative activities is overall smaller than in the case of Deputies. Regarding country effects, Italian parties ask significantly less emigration questions than the French MPs across all models.

\section{Emigration related legislative proposals}

The following four negative binomial regressions test the relevance of emigrant electoral support, party competition and the electoral system of emigrant representation for the number of emigration proposals made by each party (per chamber) in one legislature (table 6). Model 1 indicates that, similar to the analysis of non-legislative activities, emigrant electoral support is a stable and relevant predictor for emigration salience on parties' legislative agendas (H1). In incidence ratios, one percent increase in 
emigrant support increases the rate of emigration proposals by a factor of 1.05 . Regarding the second hypothesis proposed, ideology is not significant for emigration salience in legislative proposals. However, the less close is the electoral competition, that is, the larger the distance between the most voted parties, the lower the degree of emigration salience on party parliamentary agendas, confirming $\mathrm{H} 3$. For a more intuitive understanding of this result we calculate incidence ratios and observe that one percentage increase in the distance between the main parties decreases the rate of emigration initiatives by a factor of 0.98 As in the case of parliamentary questions, an electoral system with special representation is a strong predictor of emigration salience in proposals, by increasing the rate of related initiatives in one legislature by a factor of 5.00, a finding which confirms $\mathrm{H} 4$.

Table 6. Determinants of volume of emigration related legislative proposals. Negative binomial coefficients with robust standard errors

\begin{tabular}{|c|c|c|c|c|}
\hline & (1) & (2) & (3) & (4) \\
\hline \multirow{2}{*}{$\begin{array}{l}\text { Emigrant electoral } \\
\text { support }\end{array}$} & $0.047^{* * *}$ & 0.026 & $0.047^{* * *}$ & $0.045^{* * *}$ \\
\hline & $(0.013)$ & $(0.020)$ & $(0.013)$ & $(0.014)$ \\
\hline \multirow[t]{2}{*}{ Ideology } & -0.045 & -0.041 & -0.046 & $-0.200^{*}$ \\
\hline & $(0.083)$ & $(0.082)$ & $(0.083)$ & $(0.114)$ \\
\hline \multirow{2}{*}{$\begin{array}{l}\text { Closeness of electoral } \\
\text { competition }\end{array}$} & $-0.023^{*}$ & -0.019 & -0.015 & $-0.022^{*}$ \\
\hline & $(0.011)$ & $(0.012)$ & $(0.017)$ & $(0.011)$ \\
\hline \multirow[t]{2}{*}{ Special representation } & $1.609^{* * *}$ & 0.839 & $1.899^{* * * *}$ & 0.315 \\
\hline & $(0.416)$ & $(0.567)$ & $(0.523)$ & $(0.836)$ \\
\hline \multirow{2}{*}{$\begin{array}{l}\text { Special representation\# } \\
\text { Emigrant electoral } \\
\text { support }\end{array}$} & & $0.031^{*}$ & & \\
\hline & & $(0.017)$ & & \\
\hline \multirow{3}{*}{$\begin{array}{l}\text { Special representation\# } \\
\text { Closeness of electoral } \\
\text { competition }\end{array}$} & & & -0.014 & \\
\hline & & & & \\
\hline & & & $(0.024)$ & \\
\hline \multirow{2}{*}{$\begin{array}{l}\text { Special representation\# } \\
\text { Ideology }\end{array}$} & & & & $0.248^{*}$ \\
\hline & & & & $(0.131)$ \\
\hline \multirow[t]{2}{*}{ Size of party } & $0.028^{*}$ & $0.030^{*}$ & $0.028^{*}$ & $0.032^{* *}$ \\
\hline & $(0.011)$ & $(0.013)$ & $(0.011)$ & $(0.012)$ \\
\hline \multirow[t]{2}{*}{ Party in government } & -0.192 & -0.187 & -0.192 & -0.204 \\
\hline & $(0.186)$ & $(0.194)$ & $(0.194)$ & $(0.209)$ \\
\hline \multirow[t]{2}{*}{ Senate } & $-1.090^{* * *}$ & $-1.107^{* * *}$ & $-1.128^{* * *}$ & $-1.011^{* * *}$ \\
\hline & $(0.215)$ & $(0.209)$ & $(0.217)$ & $(0.204)$ \\
\hline \multirow[t]{2}{*}{ Legislature II } & -0.405 & -0.362 & -0.470 & -0.359 \\
\hline & $(0.383)$ & $(0.386)$ & $(0.382)$ & $(0.405)$ \\
\hline Legislature III & -0.020 & -0.015 & -0.144 & 0.004 \\
\hline
\end{tabular}




\begin{tabular}{|lllll|} 
& $(0.384)$ & $(0.408)$ & $(0.393)$ & $(0.402)$ \\
Spain & 0.615 & 0.433 & 0.560 & 0.538 \\
& $(0.629)$ & $(0.511)$ & $(0.647)$ & $(0.544)$ \\
Romania & -0.424 & -0.342 & -0.501 & -0.300 \\
& $(0.413)$ & $(0.414)$ & $(0.419)$ & $(0.459)$ \\
Italy & 0.224 & 0.480 & 0.116 & 0.245 \\
& $(0.422)$ & $(0.452)$ & $(0.422)$ & $(0.427)$ \\
Alpha & -0.669 & -0.408 & -0.657 & -0.013 \\
& $(0.576)$ & $(0.614)$ & $(0.580)$ & $(0.660)$ \\
\hline Observations & -0.077 & -0.209 & -0.075 & -0.144 \\
AIC & $(0.390)$ & $(0.427)$ & $(0.389)$ & $(0.378)$ \\
BIC & 130 & 130 & 130 & 130 \\
\hline
\end{tabular}

Standard errors in parenthesis

Base categories: Legislature: Legislature 1; Country: France

${ }^{*} p<0.1,{ }^{* *} p<0.01,{ }^{* * *} p<0.001$

Regarding the interaction between the electoral system and electoral incentives, the regression results indicate that electoral support has a stronger effect for parties in special representation contexts, confirming H5. Indeed, in this model electoral support is no longer significant in systems without special representation. But, unlike the case of non-legislative activities, the closeness of the electoral competition among emigrant constituents does not have a different effect depending on the electoral system. These findings suggest that in contexts with special representation, those parties, which are the most popular among emigrants (and therefore have special emigrant representatives), are more likely to seek an enduring link with emigrant voters through the emphasis on emigration issues in their legislative activities.

In order to contextualise these results, we calculate the predicted margins for various degrees of support and different configurations of electoral system. In contexts with special representation, the number of emigration related proposals increase from 1 to 9 when the votes received from abroad by the respective party increase from 0 per cent to 40 per cent. In contexts without special representation, the number of proposals increases from 0 to 2 when the votes from abroad increase from 0 to 40 per cent and is not statistically significant. 
The control variables display somewhat similar patterns in the analysis of legislative activities as in the case of the non-legislative activities. The size of the party in the chamber has a positive effect. However, as Model 4 indicates, special representation systems also significantly modify the impact of party ideology on emigration salience in legislative proposals, albeit in a minimal way. Even though the coefficient of ideology is significant, the average marginal effects of ideology over the two types of electoral systems for emigrants are small and the confidence intervals cross 0 . This means that we cannot decidedly establish if ideology has a positive or negative effect on the number of initiatives in any of the systems. Moreover, there are less emigration proposals found in the Senates which generally present a smaller volume of legislative proposals than the lower chambers. There are no significant differences between countries.

\section{Discussion and concluding remarks}

This paper set out to analyse which factors lead political parties in the country of origin to place more emphasis on emigration issues in parliamentary politics. An analysis of these processes is a timely contribution to the understanding of the transnational political link between emigrants and their homelands in the wake of the majority of world states enfranchising their non-resident citizens. As expected, external citizenship does not lead to equal attention to emigrants among political parties in the country of origin. We find strong evidence that those parties with more electoral support from the emigrants are more likely to prioritize emigrant related issues in their parliamentary activities. Moreover, close electoral races abroad increase the amount of attention dedicated to emigrant issues for legislative proposals. Further studies may explore the 
causality of these electoral links. At this point it is important to emphasize that although such findings might be intuitive at the national level, the relative uncertainty and volatility of the transnational electoral field renders this link much less obvious.

Importantly, the implementation of external electoral systems with special representation is accompanied by an increase in attention to external constituents among political parties in the homeland. In the case of parliamentary questions, the positive effect of special representation is reinforced by close electoral competition. This illustrates the different dynamics between the district level competition for special emigrant seats and the competition for the emigrant vote in legislative elections where the emigrant vote is counted as part of the general pool of votes in the country of origin. The drafting of emigration related bills displays a slightly different result, as the effect of special representation is stronger for parties who receive a larger share of votes from abroad. Together these findings suggest that the relationship between electoral competition, electoral support and party commitment to emigrant issues is more intense in systems with special emigrant representatives.

The field of transnational linkages between parties and emigrants also raises the question of which conceptual framework may better capture these processes. In a broader dialogue with theories on issue salience and representation, our analysis makes a relevant contribution by bringing both parties and constituencies back in the theoretical debate on the linkage between electorates and parliaments. The present analysis proposes an explanatory framework for the study of party emphases on constituency related issues. This complements the literature on issue salience which usually focuses on topics such as welfare, environment or European integration, which 
are not related to a particular constituency. At the same time our focus on why parties pay attention to constituency issues contributes to representation theories, which are otherwise mainly concerned with the individual behaviour of MPs.

Overall, this paper takes an important first step towards uncovering how electoral democracy works across borders between parties in the homeland and their voters residing abroad. The paper shows that the enfranchisement of emigrants does not automatically lead to more attentiveness to their plight by the political parties in the country of origin. Instead, despite the marginality of the emigrant vote, the cross border patterns of attention by parties to emigrants are related to some of the basic institutionalist conditions and strategic choices that also characterize issue salience and substantive representation on the domestic party political scene.

\section{References}

Alonso, S. \& Fonseca, S.C.D., 2012. Immigration, left and right. Party Politics, 18(6), pp.865-884.

Bauböck, R., 2007. Stakeholder citizenship and transnational political participation: a normative evaluation of external voting. Fordham Law Review, 75(5), pp.23932447.

Bélanger, É. \& Meguid, B.M., 2008. Issue salience, issue ownership, and issue-based vote choice. Electoral Studies, 27(3), pp.477-491.

Bird, K., Saalfeld, T. \& Wüst, A.M., 2010. The political representation of immigrants and minorities: voters, parties and parliaments in liberal democracies, London: Routledge.

Budge, I., 2001. Validating the manifesto research group approach. In M. Laver, ed. Estimating the policy positions of political actors. London: Routledge, pp. 50-65.

Budge, I. \& Farlie, D.J., 1983. Explaining and predicting elections: issue effects and party strategies in twenty-three democracies, London: George Allen \& Unwin.

Celis, K., 2008. Studying women's substantive representation in legislatures: when representative acts, contexts and women's interests become important. Representation, 44(2), pp.111-123. 
Collyer, M., 2014. Inside out? Directly elected "special representation" of emigrants in national legislatures and the role of popular sovereignty. Political Geography, 41, pp.64-73.

Cox, G.W. \& Munger, M.C., 1989. Closeness, expenditures, and turnout in the 1982 U.S. House elections. The American Political Science Review, 83(1), pp.217-231.

Dalton, R.J., Farrell, D.M. \& McAllister, I., 2011. Political parties and democratic linkage: how parties organize democracy, Oxford: Oxford University Press.

Ellis, A. et al., 2007. Voting from abroad: the international IDEA handbook, Stockholm: International Institute for Democracy and Electoral Assistance.

Farrell, D.M. \& Scully, R., 2005. Electing the European Parliament: how uniform are "uniform" electoral systems? JCMS: Journal of Common Market Studies, 43(5), pp.969-984.

Fiorina, M.P., 1973. Electoral origins, constituency influence, and policy moderation: a critical assessment. American Politics Research, 1(4), pp.479-498.

Green-Pedersen, C., 2010. Bringing parties into parliament: the development of parliamentary activities in Western Europe. Party Politics, 16(3), pp.347-369.

Green-Pedersen, C. \& Mortensen, P.B., 2010. Who sets the agenda and who responds to it in the Danish parliament? A new model of issue competition and agenda-setting. European Journal of Political Research, 49(2), pp.257-281.

Griffin, J.D., 2006. Electoral competition and democratic responsiveness: a defense of the marginality hypothesis. Journal of Politics, 68(4), pp.911-921.

Heitshusen, V., Young, G. \& Wood, D.M., 2005. Electoral context and MP constituency focus in Australia, Canada, Ireland, New Zealand, and the United Kingdom. American Journal of Political Science, 49(1), pp.32-45.

Hilbe, J.M., 2011. Negative Binomial Regression, Cambridge: Cambridge University Press.

Joppke, C., 2003. Citizenship between de- and re-ethnicization. European Journal of Sociology / Archives Européennes de Sociologie, 44(3), pp.429-458.

Lafleur, J.-M., 2012. Transnational politics and the state. The external voting rights of diasporas., London/New York: Routledge.

Laver, M., 2001. Estimating the policy position of political actors, London: Routledge.

Lugilde, A., 2007. O voto emigrante: viaxe pola zona escura da democracia española, Santiago de compustela: Editorial Galaxia.

Martin, S., 2011. Using parliamentary questions to measure constituency focus: an application to the Irish case. Political Studies, 59(2), pp.472-488.

Matsusaka, J.G., 1993. Election closeness and voter turnout: Evidence from California ballot propositions. Public Choice, 76(4), pp.313-334.

Mcleay, E. \& Vowles, J., 2007. Redefining constituency representation: the roles of New Zealand MPs Under MMP. Regional \& Federal Studies, 17(1), pp.71-95.

Østergaard-Nielsen, E. \& Ciornei, I., 2013. Political parties and the transnational mobilization of the emigrant vote. In Chicago: Paper presented at the MPSA conference, April 11-14.

Patzelt, W.J., 2007. The constituency roles of MPs at the Federal and Länder levels in 
Germany. Regional \& Federal Studies, 17(1), pp.47-70.

Petrocik, J.R., 1996. Issue ownership in presidential elections, with a 1980 case study. American Journal of Political Science, 40, pp.825-850.

Pitkin, H.F., 1967. The concept of representation, Oakland: University of California Press.

Pogorelis, R. et al., 2005. Issue salience in regional and national party manifestos in the UK. West European Politics, 28(5), pp.992-1014.

Powell, G.B., 2004. Political representation in comparative politics. Annual Review of Political Science, 7(1), pp.273-296.

Rhodes, S. \& Harutyunyan, A., 2010. Extending citizenship to emigrants: democratic contestation and a new global norm. International Political Science Review, 31(4), pp.470-493.

Rohrschneider, R. \& Whitefield, S., 2008. Understanding cleavages in party systems: issue position and issue salience in 13 post-communist democracies. Comparative Political Studies, 42(2), pp.280-313.

Russo, F., 2011. The constituency as a focus of representation: studying the Italian case through the analysis of parliamentary questions. The Journal of Legislative Studies, 17(3), pp.290-301.

Saalfeld, T., 2011. Parliamentary questions as instruments of substantive representation: visible minorities in the UK House of Commons, 2005-10. The Journal of Legislative Studies, 17(3), pp.271-289.

Saalfeld, T. \& Bischof, D., 2012. Parliamentary Questions as Instruments of Substantive Representation: Visible Minorities in the UK House of Commons , 2005-2011. , pp.2005-2011.

Sandu, D., 2009. Comunitati romanesti in Spania, Fundatia Soros Romania.

Tintori, G., 2012. Il voto degli altri. Rappresentanza e scelte elettorali degli italiani all'estero, Torino: Rosenberg \& Sellier.

Vliegenthart, R. \& Walgrave, S., 2011. When the media matter for politics: partisan moderators of the mass media's agenda-setting influence on parliament in Belgium. Party Politics, 17, pp.321-342.

Waldinger, R. \& Soehl, T., 2013. The bounded polity: the limits to Mexican emigrant political participation. Social Forces, 91(4), pp.1239-1266.

WorldBank, 2008. Migration and Remittances Factbook,

${ }^{1}$ Data for the Romanian Senate and legislative proposals in the first legislature of the French National Assembly are unfortunately not available in an online format.

${ }^{2}$ For further analysis of the Spanish emigrant vote see Lugilde (2007).

${ }^{3}$ For the sake of simplicity, we use the term parliamentary questions, although the numbers include interpellations as well.

${ }^{4}$ For instance, in the case of Spain, MPs may submit the same question repeatedly only changing the name of the country of residence of Spanish emigrants or 
district of origin. We have grouped these questions together. Moreover, we have run the same regressions with these repetitions and the significance does not change.

${ }^{5}$ The information in the parliamentary database of the French Senate is ordered per parliamentary group only. However, these parliamentary groups largely coincide with the parties except for a smallish group of non-affiliated deputies and senators

${ }^{6}$ We have adapted the rolling elections in the French Senate to the legislative election dates of the National Assembly by averaging the electoral support of the AFE within those periods.

${ }^{7}$ A small number of parties in our dataset are missing from the CHES dataset. We have estimated their ideology scores based on primary sources (party web page, latest electoral manifesto) and secondary sources (ParlGov and Comparative Manifesto project). These parties are: France: Mouvement des citoyens (4). Italy: Per l'Italia nell Mondo (8), Associazione Italia Sud America (5), Movimento Associativo per Italiani nell Estero (5.33). Spain: Iniciativa per Catalunya Verts (3). Romania: National Minorities (5).

${ }^{8}$ Such dummies might also help control for systemic differences generated by the parliamentary search engines across the different cases 
Table 1. Main characteristics of the emigrant electorate and electoral system in France, Italy, Romania and Spain

\begin{tabular}{|c|c|c|c|c|c|c|}
\hline \multirow[t]{3}{*}{ Country } & Emigrants & \multirow{3}{*}{$\begin{array}{l}\text { Main regions and countries of } \\
\text { residence }\end{array}$} & \multirow{3}{*}{$\begin{array}{l}\text { Voting rights } \\
\text { since }\end{array}$} & \multirow{3}{*}{$\begin{array}{l}\text { Special emigrant } \\
\text { representatives since }\end{array}$} & \multirow{3}{*}{$\begin{array}{l}\text { Turnout, recent } \\
\text { elections }\end{array}$} & \multirow[t]{3}{*}{ Voting pattern } \\
\hline & $\begin{array}{l}\text { Emigrant } \\
\text { voters }\end{array}$ & & & & & \\
\hline & $\begin{array}{l}\text { \% over total } \\
\text { electorate }\end{array}$ & & & & & \\
\hline \multirow[t]{3}{*}{ France } & 1611054 & \multirow{3}{*}{$\begin{array}{l}\text { Europe (Switzerland, UK), North } \\
\text { America, Middle East (Israel), North } \\
\text { Africa (Morocco) }\end{array}$} & 1981 presidential & $\begin{array}{l}2008 \text { (2012) National } \\
\text { Assembly: } 11 \mathrm{MPs}\end{array}$ & \multirow{3}{*}{$\begin{array}{l}39,1 \% \text { in } 2012 \\
\text { (presidential) } \\
20,9 \% \text { in } 2012 \\
\text { (legislative) }\end{array}$} & \multirow[t]{3}{*}{$\begin{array}{l}\text { More support for } \\
\text { centre right until } 2012\end{array}$} \\
\hline & 1067000 & & 2008 legislative & 1958 Senate: 12 MPs & & \\
\hline & 2,3 & & & & & \\
\hline \multirow[t]{3}{*}{ Italy } & 4341156 & \multirow{3}{*}{$\begin{array}{l}\text { Europe (Germany, Switzerland) South } \\
\text { America (Argentina), North America. } \\
\text { Australia. }\end{array}$} & \multirow[t]{3}{*}{$\begin{array}{l}2001 \text { (first } \\
\text { election 2006) }\end{array}$} & $\begin{array}{l}2001 \text { (2006) Chamber of } \\
\text { Deputies: } 12 \mathrm{MPs}\end{array}$ & \multirow{3}{*}{$\begin{array}{l}31,6 \% \text { in } 2013 \\
\text { (legislative, Chamber of } \\
\text { Deputies) }\end{array}$} & \multirow[t]{3}{*}{$\begin{array}{l}\text { More support for the } \\
\text { centre left }\end{array}$} \\
\hline & 3494687 & & & $\begin{array}{l}2001 \text { (2006) Senate: } 6 \\
\text { MPs }\end{array}$ & & \\
\hline & 7,5 & & & & & \\
\hline \multirow[t]{2}{*}{ Romania } & $3007350 *$ & \multirow[t]{2}{*}{ Europe (Italy, Spain), North America } & 1991 presidential & $\begin{array}{l}\text { 2008 Chamber of } \\
\text { Deputies: } 4 \text { MPs }\end{array}$ & $\begin{array}{l}\text { 147,754 voters in } 2009 \\
\text { (presidential) }\end{array}$ & \multirow[t]{2}{*}{ Volatile } \\
\hline & & & 2007 legislative & 2008 Senate: 2 MPs & $\begin{array}{l}61,014 \text { in } 2012 \\
\text { (legislative) }\end{array}$ & \\
\hline \multirow[t]{3}{*}{ Spain } & 1702778 & \multirow[t]{3}{*}{$\begin{array}{l}\text { South America (Argentina) Europe } \\
\text { (France, Germany) }\end{array}$} & \multirow[t]{3}{*}{1978} & Congress: None & \multirow{3}{*}{$\begin{array}{l}31,74 \% \text { in } 2008 \\
5 \% \text { in } 2011\end{array}$} & \multirow[t]{3}{*}{$\begin{array}{l}\text { Always vote for } \\
\text { incumbent party }\end{array}$} \\
\hline & 1482786 & & & & & \\
\hline & 4,1 & & & Senate: None & & \\
\hline
\end{tabular}

Own elaboration from: Ellis et al (2007); http://www.idea.int/vt/; France: Rapport du Gouvernement sur la situation des Français établis hors de France 2012; http://www.diplomatie.gouv.fr; http://www.interieur.gouv.fr/Elections/Les-resultats Italy: http://elezionistorico.interno.it/; AIRE, http://servizidemografici.interno.it; Romania: http://www.becparlamentare2012.ro/: http://www.bec2009p.ro; United Nations, Department of Economic and Social Affairs (2013). Trends in International Migrant Stock: Migrants by Destination and Origin, Spain: Pere, http://www.ciudadaniaexterior.empleo.gob.es; http:/www.infoelectoral.interior.es/min/. *Due to the lack of registration of Romanian voters abroad we only have the number first generation Romanians abroad and the turnout is in absolute numbers. Numbers of emigrants, registered voters and turnout is from the last election within the period studied. 